\title{
p-NITROPHENYLGLYCEROL-A SUPERIOR ANTISWARMING AGENT FOR ISOLATING AND IDENTIFYING PATHOGENS FROM CLINICAL MATERIAL
}

\author{
B. W. SENIOR \\ Department of Bacteriology, University of Dundee, Dundee DD1 9SY
}

THE isolation of pathogenic bacteria from specimens sent to the bacteriology laboratory is often difficult if swarming strains of Proteus species are also present. In certain instances the conventional antiswarming agents-sodium azide, bile salts, $5 \%$ alcohol and chloral hydrate-are helpful. However, these substances are unsuitable for the isolation and identification of many pathogens; they are toxic for many species and the recognition of bacteria that cause characteristic haemolysis on blood agar is hampered by the agents' lytic action on red blood cells (Krämer and Koch, 1931; Floyd and Dack, 1939; Snyder and Lichstein, 1940; Lominski and Lendrum, 1942).

Kopp, Müller and Lemme (1966) reported that very low concentrations of $p$-nitrophenylglycerol (PNPG) in media prevented swarming but had no effect on the growth or motility of Proteus mirabilis. This paper reports that PNPG is more useful than conventional antiswarming agents. PNPG has proved invaluable in this laboratory in the recognition, isolation and rapid identification of small numbers of many different pathogenic bacteria from specimens such as cervical and abdominal wound swabs that are frequently heavily contaminated with strains of swarming Proteus spp.

\section{MATERIALS AND METHODS}

Bacterial strains. Several strains of each of the following species were isolated in pure culture from clinical specimens sent for routine bacteriological examination: Staphylococcus aureus, Staph. albus, Streptococcus pyogenes, Str. agalactiae, Str. viridans, Str. faecalis, Str. pneumoniae, Salmonella dublin, Salm. typhimurium, Neisseria gonorrhoeae, N. meningitidis, Haemophilus influenzae, Proteus mirabilis, P. vulgaris, Clostridiumperfringens, Bacteroides spp. and anaerobic streptococci.

Media. $p$-Nitrophenylglycerol (PNPG) was purchased from the Sigma Chemical Co. Ltd, London. Blood agar and heated-blood ("chocolate ") agar were prepared from Blood Agar Base (CM 55; Oxoid) and 5\% defibrinated horse blood (SR 50; Oxoid). PNPG was added to these media either (i) as a solid, immediately before autoclaving for $15 \mathrm{~min}$. at $121^{\circ} \mathrm{C}$, or (ii) as an aqueous solution, sterilised by Millipore filtration, to autoclaved media after cooling.

Examination of strains. The colonial morphology, haemolysis, reaction with Gram's stain, microscopical appearance and results of primary antibiotic-sensitivity tests of each strain grown on media with and without PNPG were examined. In addition, the following diagnostic tests were performed on colonies of particular species picked from plates with and without PNPG: slide coagulase, catalase, oxidase, slide agglutination (salmonella $\mathrm{O}$ and $\mathrm{H}$ ), optochin and bacitracin sensitivity, and Lancefield grouping (Phadebact Streptococcus Test; Pharmacia, Uppsala, Sweden).

Tests for toxicity. Colonies of $N$. gonorrhoeae were picked from chocolate-agar plates and resuspended in saline. Serial dilutions of the suspension were made in saline and plated out on several chocolate-agar plates that contained concentrations of PNPG ranging from 0.2 to $1.0 \mathrm{mM}$, and on control plates without PNPG. After incubation for $48 \mathrm{~h}$ at $37^{\circ} \mathrm{C}$ in an atmosphere of $8 \% \mathrm{CO}_{2}$ in air, the number of colonies on each plate was counted.

Received 9 June 1977; accepted 27 July 1977. 


\section{RESULTS}

PNPG was found to be a stable compound that readily dissolved in water to form a solution of neutral $p \mathrm{H}$; sterilisation by autoclaving and storage for several months at $4^{\circ} \mathrm{C}$, either as a pure compound or after addition to media, did not affect its antiswarming properties. PNPG was very effective as an antiswarming agent; concentrations as low as $0.2 \mathrm{mM}(0.43 \mathrm{mg}$ of PNPG in $100 \mathrm{ml}$ of medium) prevented swarming of most Proteus strains, but all the test strains grew well in concentrations of PNPG five times greater than this. PNPG concentrations of $0.2-0.4 \mathrm{mM}$ were usually satisfactory for the isolation of species that required only overnight incubation for growth. However, some strains of Proteus spp. tended to start swarming after prolonged incubation at these concentrations and better results were obtained with PNPG concentrations of $0.8-1.0 \mathrm{mM}$ for strains that required $48-72 \mathrm{~h}$ for growth.

When mixed cultures of each of the test organisms (see Methods) and swarming strains of $P$. mirabilis were plated out on media containing the PNPG concentrations suggested above, the test strains were easily isolated in pure culture. This was usually impossible in the absence of PNPG. The number of colonies of $N$. gonorrhoeae on the plates containing concentrations of PNPG from 0.2 to $1.0 \mathrm{mM}$ varied by about $20 \%$. This variation was random and showed no relationship to increasing PNPG concentrations.

It had been the original intention to use PNPG solely to facilitate the isolation of pathogens in the presence of Proteus spp. and subsequently to identify them after subculture from PNPG plates. However, it was found that most organisms could be identified directly from the PNPG medium. Growth in the presence of PNPG did not significantly affect any of the pathogens in respect of their colonial size and morphology, haemolytic reactions, staining properties or microscopic appearance. Moreover, the results of various tests-slide coagulase, Lancefield typing, catalase, oxidase, slide agglutination (salmonella $\mathbf{O}$ and $\mathbf{H}$ ) performed on colonies picked directly from the PNPG plates, were identical to the results obtained with colonies grown in the absence of PNPG. When the sensitivities of the test organisms to optochin, bacitracin and a wide variety of antibiotics were tested by applying "Multodisks" (Oxoid) to plates, with and without PNPG, that had been evenly inoculated on a rotary plating machine, PNPG affected neither the pattern of antibiotic sensitivity nor the zone sizes.

\section{Discussion}

Small numbers of important pathogens may not be detected when infected material is heavily contaminated with strains of swarming Proteus spp. The conventional antiswarming agents are often unsatisfactory because they may be toxic for the pathogen and prevent growth or may alter the characteristics by which the pathogens are usually recognised. The use of the antiswarming agent $p$-nitrophenylglycerol (PNPG) overcomes these difficulties. PNPG has many properties that make it superior to other antiswarming agents. It is relatively cheap, non-toxic and does not affect red blood cells; even fastidious pathogens will grow well and with characteristic morphology in its presence. Its heat stability and long "shelf life" make it convenient to use in the preparation of media, without wastage. As there is no need to subculture organisms on medium without PNPG before performing identification tests, much time, material and expense are saved.

The way in which PNPG prevents swarming is unknown. Kopp et al. (1966) showed that it had no effect on the morphology or function of proteus flagella and suggested that it affected the mechanism of swarming, possibly by interference with the mechanism of negative chemotaxis proposed by Lominski and Lendrum (1947). Senior (1977) showed that it did not affect bacteriocine production or sensitivity in $\boldsymbol{P}$. mirabilis strains. It is unlikely therefore to have a great effect on surface antigens and it may be possible to identify many different organisms in addition to salmonellae by serotyping colonies grown on media containing PNPG. 


\section{SUMMARY}

The antiswarming agent $p$-nitrophenylglycerol (PNPG) has been found invaluable for the recognition and isolation of pathogenic bacteria from specimens contaminated with swarming strains of Proteus spp. PNPG is cheap, stable and non-toxic. All strains tested grew well in its presence and produced characteristic morphology. PNPG was without effect on the results of a variety of identification tests performed directly on colonies from media containing PNPG. This permitted identification without the need for further subculture.

\section{REFERENCES]}

Floyd, T. M. AND DACK, G. M. 1939. The isolation of Bacterium necrophorum in the presence of Proteus. J. infect. Dis., 64, 269.

Kopp, R., Müller, J. AND Lemme, R. 1966. Inhibition of swarming Proteus by sodium tetradecyl sulfate, $\beta$-phenylethyl alcohol, and $p$-nitrophenylglycerol. Appl. Microbiol., 14, 873.

KrÄmer, E. AND KoCH, F. E. 1931. Hemmung des Schwärmens der Proteuskolonien durch Chloralhydrat, verglichen mit der Hemmung durch Dextrose, $42^{\circ}$-Züchtung, Phenol, Natriumchlorid, Wismut, Esbachs Reagenz, Malachitgrün, Galle und Kupfersulfat. Zentbl. Bakt. ParasitKde, I. Abt. Orig., 120, 452.

Lominski, I. AND LendRuM, A. C. 1942. The effect of surface-active agents on $B$. proteus. J. Path. Bact., 54, 421.

Senior, B. W. 1977. The Dienes Phenomenon: identification of the determinants of compatibility. J. gen. Microbiol., 102, 235.

SNyDER, M. L. AND Lichstein, H. C. 1940. Sodium azide as an inhibiting substance for gram negative bacteria. J. infect. Dis., 67, 113 . 